\title{
Charakterystyka złączy stopów aluminium serii 5xxx i 7xxx wykonanych metodą zgrzewania tarciowego z mieszaniem materiału
}

\author{
Characterization of friction stir \\ welded 5xxx and 7xxx aluminum alloys
}

\section{Streszczenie}

W artykule przedstawiono charakterystykę mikrostrukturalną oraz mechaniczną doczołowych złączy stopów aluminium 5083-H111 i 7075-T651 wykonanych metodą zgrzewania tarciowego z mieszaniem materiału (FSW). Stop 5083 to spawalny stop Al-Mg, natomiast stop 7075 należy do stopów Al-Zn-Mg-Cu, które są uznawane za niespawalne przy użyciu tradycyjnych technik spawania. Metoda FSW przy zastosowaniu odpowiednich parametrów procesu pozwoliła na uzyskanie trwałego złącza bez defektów spawalniczych pomiędzy tymi stopami, charakteryzującego się bardzo dobrymi właściwościami wytrzymałościowymi. Wytrzymałość na rozciąganie złączy jest niższa niż stopu 7075, ale wyższa od wytrzymałości stopu 5083. Badania przeprowadzone dla dwóch konfiguracji złącza (umiejscowienie stopu 7075 po stronie natarcia i stopu 5083 po stronie spływu oraz odwrotna konfiguracja) wykazały, że konfiguracja złącza ma istotny wpływ na wymieszanie materiałów w strefie mieszania, ale nie zaobserwowano istotnego wpływu na właściwości wytrzymałościowe złącza. W przypadku konfiguracji 5083-7075 i zastosowanego narzędzia z trzpieniem typu Triflute występuje lepsze wymieszanie materiałów.

Słowa kluczowe: zgrzewanie tarciowe z przemieszaniem, stopy aluminium

\begin{abstract}
The microstructure and mechanical properties of dissimilar friction stir welded 5083-H111 and 7075T651 aluminum alloys were studied. The 5083 alloy is weldable Al-Mg alloy and 7075 alloy belongs to Al$\mathrm{Zn}-\mathrm{Mg}-\mathrm{Cu}$ alloys, which are classified as unweldable by using conventional welding methods. The application appropriate parameters of friction stir welding process enables obtaining of sound weld between these alloys with good mechanical properties. The joint shows lower tensile strength compared to the 7075 alloy, but higher than 5083 alloy. The investigation performing for two weld configuration ( 7075 alloy on the advancing side and 5083 alloy on the retreating side as well as reverse configuration) reveals that configuration influences on a mixing of materials in stirred zone, but effect on properties is not observed. The weld configuration 50837075 was characterized by more complex microstructure in the stirred zone.
\end{abstract}

Keywords: friction stir welding, aluminium alloys

dr inż. Izabela Kalemba, dr inż. Mateusz Kopyściański - Akademia Górniczo-Hutnicza, Kraków, mgr inż. Damian Miara, dr inż. Krzysztof Krasnowski - Instytut Spawalnictwa, Gliwice. 


\section{Wstęp}

Wielomateriałowe konstrukcje stanowią wyzwanie dla metod spajania, gdyż istotnym aspektem inżynierskim jest możliwość uzyskania trwałego połączenia pomiędzy elementami konstrukcji. Największe trudności pojawiają się, jeśli wymagane jest połączenie dwóch materiałów charakteryzujących się różną mikrostrukturą i właściwościami. Powszechnie w przypadku łączenia materiałów metalicznych stosuje się spawanie, zgrzewanie oraz lutowanie. Jednakże spawanie (zarówno łukowe, jak i wiązką laserową czy elektronową), ze względu na występującą strefę stopienia łączonych materiałów, ma bardzo ograniczone zastosowanie uniemożliwiając uzyskanie trwałego złącza o wymaganych właściwościach w przypadku łączenia materiałów trudno lub $w$ ogóle niespawalnych. Na spajanie materiałów bez przetopienia pozwalają metody zgrzewania i lutowania, gdzie do łączenia wykorzystywane są różne zjawiska fizyczne, tj. tarcie, dyfuzja, odkształcenie plastyczne. Rozwój tych metod daje możliwość wytwarzania złączy różnoimiennych materiałów, szczególnie tych niespawalnych [1].

Jedną z najatrakcyjniejszych w ostatnich latach metod łączenia $w$ stanie stałym jest metoda FSW (friction stir welding) zgrzewania tarciowego $\mathrm{z}$ mieszaniem materiału. W porównaniu z klasycznymi metodami spajania, FSW jest techniką ekologiczną, tzn. nie powoduje emisji gazów spawalniczych, hałasu, czy też powstawania żużla i pól magnetycznych. Początkowo proces FSW był opracowany dla łączenia stopów aluminium, szczególnie tych niemożliwych do połączenia metodami konwencjonalnymi. Obecnie za pomocą FSW można otrzymać odpowiedniej jakości złącza także innych materiałów np. miedzi, magnezu, tytanu, cynku, stali i stopów niklu. Metoda FSW świetnie sprawdza się do połączeń materiałów jednoimiennych, to jest materiałów o jednakowych właściwościach mechanicznych, ale także umożliwia spajanie materiałów różnorodnych, np. różnych kombinacji stopów aluminium, stopy magnezu-tytan, aluminium-miedź, stopy aluminium-stal $[2 \div 4]$.

Jednakże proces zgrzewania FSW materiałów o różnych właściwościach, nazywanych w skrócie różnoimiennymi, różni się od łączenia materiałów o jednakowych właściwościach. W przypadku złączy różnoimiennych możliwość uzyskania złącza i mechanizm jego tworzenia jest uzależniony od różnej podatności na odkształcenie plastyczne łączonych materiałów, ich różnych właściwości fizycznych (tj. temperatura topnienia, przewodnictwo cieplne) oraz konfiguracji złącza, czyli umiejscowienia danego stopu po stronie natarcia lub po stronie spływu. Te czynniki powodują asymetrię $w$ generowaniu ciepła oraz przepływie materiału podczas procesu. Pomimo prowadzenia intensywnych badań w wielu światowych ośrodkach naukowych proces FSW, w szczególności w odniesieniu do łączenia różnych materiałów, nie jest do końca poznany $[3,5,6]$.

W pracy przedstawiono charakterystykę połączeń pomiędzy dwoma różnymi gatunkami stopów aluminium (stopu umacnianego przez odkształcenie z serii $5 x x x$ i niespawalnego stopu umacnianego wydzieleniowo z serii $7 x x x$ ) wykonanych metodą zgrzewania tarciowego $z$ mieszaniem materiału.

\section{Przedmiot badań}

Przedmiotem badań były złącza stopów aluminium: umacnianego odkształceniowo stopu Al-Mg: 5083$\mathrm{H} 111$ oraz umacnianego wydzieleniowo stopu Al-ZnMg-Cu: 7075-T651. Skład chemiczny stopów podano w tablicy I.

Blachy o grubości $6 \mathrm{~mm}$ zostały połączone doczołowo metodą zgrzewania tarciowego $z$ mieszaniem materiału. Proces zgrzewania wykonano $w$ Instytucie Spawalnictwa w Gliwicach. Stanowisko do zgrzewania pokazano na rysunku 1a. Zastosowane narzędzie składało się ze spiralnego kołnierza i trzpienia typu Triflute (rys.1b).

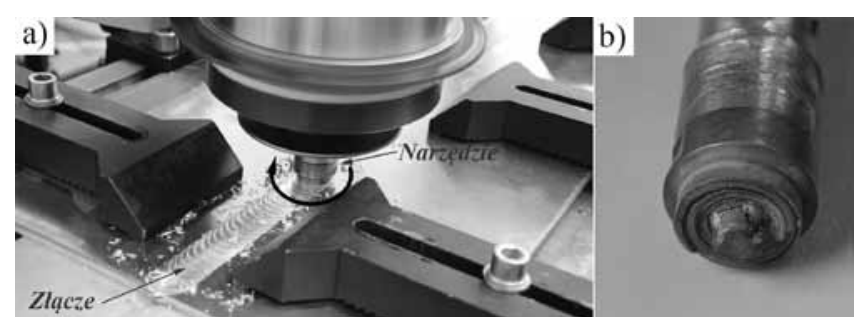

Rys. 1. a) Schemat procesu zgrzewania; b) narzędzie FSW z trzpieniem typu Triflute

Fig. 1. a) A scheme of friction stir welding process; b) tool with fixed Triflute pin

Tablica I. Skład chemiczny łączonych stopów, \% wag.

Table I. Chemical composition of joined alloys, \% wt

\begin{tabular}{|c|c|c|c|c|c|c|c|c|c|}
\hline Stop & $\mathrm{Mg}$ & $\mathrm{Zn}$ & $\mathrm{Cu}$ & $\mathrm{Mn}$ & $\mathrm{Si}$ & $\mathrm{Fe}$ & $\mathrm{Cr}$ & $\mathrm{Ti}$ & Al \\
\hline 5083 & 4,32 & 0,04 & 0,05 & 0,56 & 0,16 & 0,36 & 0,06 & 0,05 & Reszta \\
\hline \multicolumn{10}{|c|}{$\begin{array}{l}\text { H111 - wyżarzony i nieznacznie umocniony przez walcowanie } \\
\text { H111 - anneald and slightly hardened by rolling }\end{array}$} \\
\hline 7075 & 2,56 & 6,18 & 1,86 & 0,02 & 0,13 & 0,15 & 0,21 & 0,04 & Reszta \\
\hline
\end{tabular}


Zgrzewanie wykonano przy stałej prędkości zgrzewania $140 \mathrm{~mm} / \mathrm{min}$ i różnych prędkościach obrotowych: $280 \mathrm{obr} / \mathrm{min}, 355 \mathrm{obr} / \mathrm{min}, 450 \mathrm{obr} / \mathrm{min}$ oraz $560 \mathrm{obr} / \mathrm{min}$. Proces zgrzewania przeprowadzono w dwóch konfiguracjach: w pierwszej stop 7075 znajdował się po stronie natarcia, a stop 5083 po stronie spływu (7075-5083), natomiast w drugiej blachy ułożono odwrotnie: stop 5083 po stronie natarcia - stop 7075 po stronie spływu (5083-7075). Podczas procesu zgrzewania za pomocą głowicy pomiarowej Lowstir przeprowadzono badania siły i momentu siły, na podstawie których wyznaczono moc cieplną i całkowitą energię wprowadzaną do złącza. Otrzymane złącza poddano ocenie pod względem mikrostrukturalnym i właściwości mechanicznych (pomiar twardości i próba rozciągania). Do obserwacji mikrostruktury wykorzystano mikroskop świetlny Axio Imager firmy ZEISS. Próbki metalograficzne przygotowano z przekroju prostopadłego do kierunku zgrzewania złączy. Po szlifowaniu i polerowaniu próbki poddano anodyzowaniu w elektrolicie zawierającym $1,8 \mathrm{ml} \mathrm{HBF}{ }_{4}$ i $100 \mathrm{ml}$ wody. Obserwacje prowadzono $\mathrm{w}$ świetle spolaryzowanym. Pomiary twardości wykonano na twardościomierzu Tukon 2500 metodą Vickersa na przekroju prostopadłym do kierunku zgrzewania złączy wzdłuż linii leżącej $w$ połowie grubości złącza. Odległość pomiędzy punktami pomiarowymi wynosiła $1 \mathrm{~mm}$. Zastosowano obciążenie wgłębnika siłą 9,81 N przez 10 sekund. Przy użyciu maszyny wytrzymałościowej MTS 810 przeprowadzono próbę rozciągania próbek zmateriałurodzimegoorazpróbekpozgrzewaniu.Próbki $z$ materiału zgrzewanego wycięto $w$ taki sposób, że oś rozciągania była prostopadła do zgrzeiny, a zgrzeina znajdowała się w środku długości pomiarowej próbki.

\section{Wyniki badań}

\section{Energia}

W czasie trwania procesu zgrzewania, ciepło jest generowane $z$ dwóch źródeł: $w$ wyniku tarcia powierzchni narzędzia o zgrzewane materiały oraz w wyniku deformacji materiału w mikroobszarze wokół narzędzia [6]. Obliczenia mocy cieplnej w danej chwili tarcia wykonano przy założeniu, że zjawiska zachodzące podczas procesu FSW są takie same jak w procesie zgrzewania tarciowego (zjawiska zachodzące pomiędzy narzędziem a powierzchnią zgrzewanych materiałów). Na tej podstawie moc cieplną na powierzchni styku narzędzie moc cieplną obliczono z następującej zależności (1):

$$
N_{\mathrm{CQ}}=M t \cdot 2 \pi \cdot \omega
$$

gdzie:

$\mathrm{N}_{\mathrm{cQ}}-$ moc cieplna, $\mathrm{W}$

$\mathrm{Mt}$ - moment obrotowy, Nm

$\omega$ - prędkość obrotowa narzędzia, obr/s

Wyniki obliczeń mocy cieplnej, generowanej w danej chwili, dla wykonanych konfiguracji złączy 7075 -5083 i 5083-7075 przedstawiono w tablicy II.

Następnie dokonano obliczenia całkowitej ilości energii, wprowadzonej na całej długości złącza w stanie ustabilizowanym, ze wzoru (2):

$$
E=\mathrm{N}_{\mathrm{CQ}} \cdot t
$$

gdzie:

$E$ - całkowita ilość energii wprowadzona do złącza, kJ $\mathrm{N}_{\mathrm{CQ}}$ - moment obrotowy, $\mathrm{Nm}$

$\omega$ - prędkość obrotowa narzędzia, obr/s

Wyniki tych obliczeń przedstawiono w tablicy III dla złączy 7075-5083 i tablicy IV dla złączy 5083-7075.

Tablica II. Moc cieplna w złączach dla konfiguracji 7075-5083 i 5083-7075

Table II. Thermal power in welds for $7075-5083$ and $5083-7075$ configurations

\begin{tabular}{|c|c|c|c|c|c|}
\hline \multicolumn{2}{|c|}{ Prędkość obrotowa narzędzia, $\omega$} & \multicolumn{2}{|c|}{ Konfiguracja 7075-5083 } & \multicolumn{2}{c|}{ Konfiguracja 5083-7075 } \\
\hline obr./min & obr./s & $\begin{array}{c}\text { Moment obrotowy } \\
\text { Mt, Nm }\end{array}$ & $\begin{array}{c}\text { Moc cieplna, } \\
\mathrm{N}_{\mathrm{cQ}}, \mathrm{W}\end{array}$ & $\begin{array}{c}\text { Moment obrotowy } \\
\text { Mt, Nm }\end{array}$ & Moc cieplna, W \\
\hline 280 & 4,7 & 72,2 & 2116,5 & 82,3 & 2410,8 \\
\hline 355 & 5,9 & 57,2 & 2125,4 & 64,0 & 2381,0 \\
\hline 450 & 7,5 & 44,8 & 2110,1 & 44,9 & 2116,4 \\
\hline 560 & 9,3 & 35,7 & 2090,9 & 34,3 & 2008,9 \\
\hline
\end{tabular}

Tablica III. Całkowita ilość energii wprowadzonej do złącza na ustabilizowanym odcinku, konfiguracja 7075-5083

Table III. The total amount of energy input to weld in the stabilized section, 7075-5083 configuration

\begin{tabular}{|c|c|c|c|c|c|}
\hline $\begin{array}{c}\text { Prędkość } \\
\text { obrotowa } \\
\text { narzędzia } \omega, \\
\text { obr./min }\end{array}$ & $\begin{array}{c}\text { Długość zgrzeiny } \\
\text { w stanie } \\
\text { ustabilizowanym } \\
\mathrm{s}, \mathrm{m}\end{array}$ & $\begin{array}{c}\text { Prędkość } \\
\text { zgrzewania } \\
\text { Vz, m/min }\end{array}$ & $\begin{array}{c}\text { Czas zgrzewania } \\
\text { w stanie } \\
\text { ustabilizowanym } \\
\mathrm{t}, \mathrm{min}\end{array}$ & Moc cieplna, W & $\begin{array}{c}\text { Całkowita ilość } \\
\text { energii E, kJ }\end{array}$ \\
\hline 280 & 0,1 & 0,14 & 0,71 & 2116,5 & 90,71 \\
\hline 355 & 0,1 & 0,14 & 0,71 & 2125,4 & 91,09 \\
\hline 450 & 0,1 & 0,14 & 0,71 & 2110,1 & 90,43 \\
\hline 560 & 0,1 & 0,14 & 0,71 & 1090,9 & 89,61 \\
\hline
\end{tabular}


Tablica IV. Całkowita ilość energii wprowadzonej do złącza na ustabilizowanym odcinku, konfiguracja 5083-7075 Table IV. The total amount of energy input to weld in the stabilized section, 5083-7075 configuration

\begin{tabular}{|c|c|c|c|c|c|}
\hline $\begin{array}{c}\text { Prędkość obrotowa } \\
\text { narzędzia } \omega \\
\text { obr./min }\end{array}$ & $\begin{array}{c}\text { Długość zgrzeiny } \\
\text { w stanie } \\
\text { ustabilizowanym s, m }\end{array}$ & $\begin{array}{c}\text { Prędkość } \\
\text { zgrzewania } \\
\text { Vz, m/min }\end{array}$ & $\begin{array}{c}\text { Czas zgrzewania } \\
\text { w stanie } \\
\text { ustabilizowanym t, min }\end{array}$ & $\begin{array}{c}\text { Moc cieplna } \\
\text { W }\end{array}$ & $\begin{array}{c}\text { Całkowita ilość } \\
\text { energii E } \\
\text { kJ }\end{array}$ \\
\hline 280 & 0,1 & 0,14 & 0,71 & 2410,8 & 103,32 \\
\hline 355 & 0,1 & 0,14 & 0,71 & 2381,0 & 101,91 \\
\hline 450 & 0,1 & 0,14 & 0,71 & 2116,4 & 90,70 \\
\hline 560 & 0,1 & 0,14 & 0,71 & 2008,9 & 86,10 \\
\hline
\end{tabular}

Powyższe zależności przedstawiono w formie wykresów na rysunku 2.
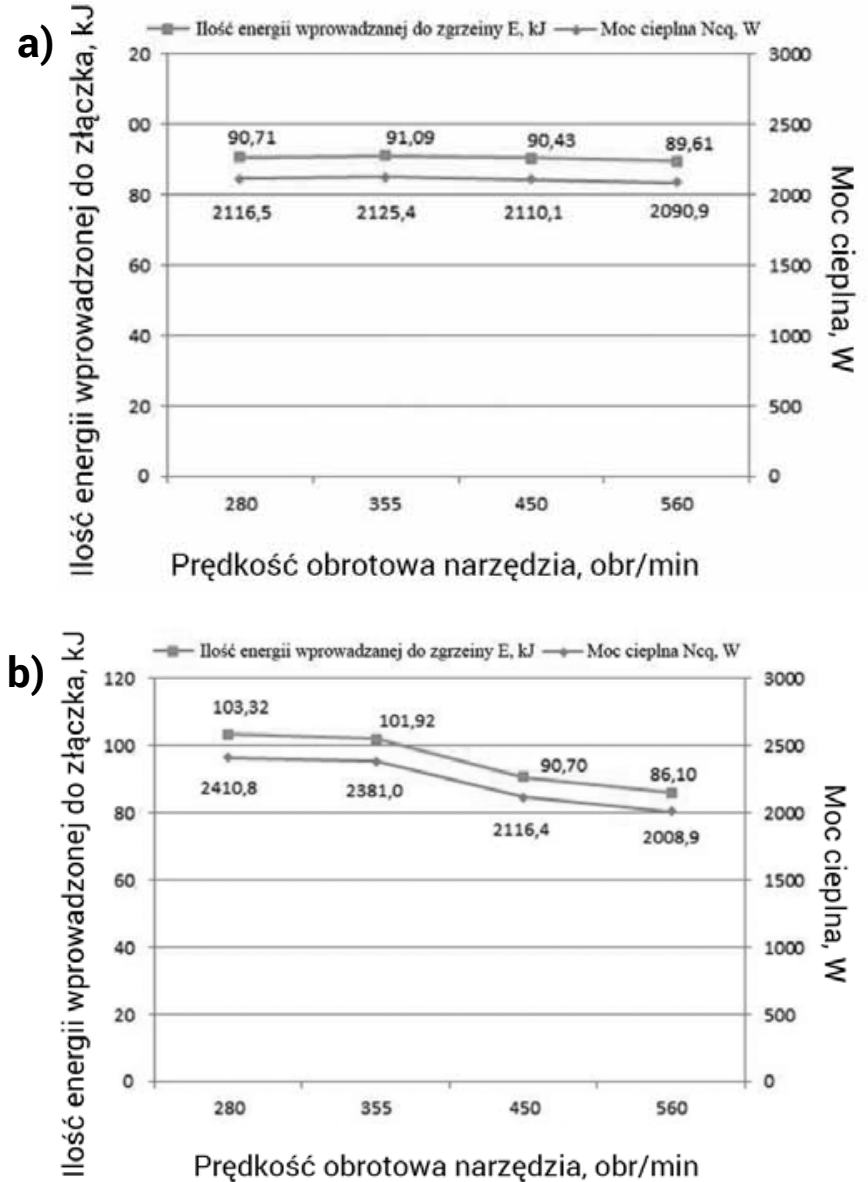

Rys. 2. a) Wpływ prędkości obrotowej narzędzia na ilość energii wprowadzanej do złącza i moc cieplną a) konfiguracja 7075-5083, b) konfiguracja $5083-7075$

Fig. 2. I Influence of tool rotation speed on the amount of energy input to weld and thermal power input in the case of a) 7075-5083 configuration, b) 5083-7075 configuration

Szczegółowa analiza wyników pozwala określić, że wraz ze zwiększaniem prędkości obrotowej narzędzia, nieznacznie spada ilość energii wprowadzanej do złącza, przy czym spadek ten jest bardziej widoczny przy usytuowaniu stopu 5083 po stronie natarcia (rys. 2b). Podobnie jest przy określaniu mocy cieplnej procesu. Mimo znacznie niższych wartości momentu obrotowego, wraz ze zwiększaniem prędkości obrotowej narzędzia, obniżenie mocy cieplnej nie jest tak gwałtowne.

\section{Makrostruktura}

Na rysunku 3 zestawiono makrostrukturę przekroju poprzecznego złączy wykonanych przy różnej prędkości obrotowej, odpowiednio dla konfiguracji złącza: stop 7075 po stronie natarcia - stop 5083 po stronie spływu oraz stop 5083 po stronie natarcia - stop 7075 po stronie spływu. Przy niższych prędkościach obrotowych (280 obr./min i 355 obr./min) otrzymano złącza bez niegodności spawalniczych, lecz wymieszanie materiałów szczególnie w złączach 7075-5083 jest niewielkie. Zastosowanie wyższych prędkości (450 obr./ min i 560 obr./min), spowodowało lepsze wymieszanie materiałów w obszarze złącza, ale doprowadziło do pojawienia się wad, głównie porowatości. Pory widoczne są w środkowej części złączy, tj. w strefie mieszania. W przypadku złączy 7075-5083 są one rozleglejsze.

Pomimo podobnego wpływu prędkości obrotowej narzędzia na występowanie defektów i stopień wymieszania materiałów dla obu konfiguracji złącza, obserwacje makrostruktury ujawniają znaczne różnice $\mathrm{w}$ mieszaniu materiałów podczas procesu zgrzewania w zależności od konfiguracji złącza. W przypadku konfiguracji 7075-5083 obserwowane jest mniejsze wymieszanie materiału niż dla złączy w konfiguracji 5083-7075. W konfiguracji złącza 5083-7075 dla prędkości $280 \mathrm{obr} / \mathrm{min}$ i $355 \mathrm{obr}$./min widoczne jest tzw. "jądro zgrzeiny", umiejscowione w dolnej części zgrzeiny, które zanika wraz ze wzrostem prędkości obrotowej narzędzia. W złączach, za wyjątkiem złączy 7075-5083 wykonanych przy prędkościach 280 obr./ $\mathrm{min}$ i $355 \mathrm{obr} / \mathrm{min}$, materiały mieszają się $\mathrm{w}$ taki sposób, że tworzą po stronie natarcia strukturę zbliżoną do "pierścieni cebuli". Struktura ta złożona jest z pasm pochodzących od stopu 7075 i stopu 5083 ułożonych naprzemiennie. Wraz ze wzrostem prędkości obrotowej narzędzia, ta struktura staje się wyraźniejsza.

Prędkość obrotowa ma głównie wpływ na ciepło wytwarzane podczas tworzenia złącza. Dodatkowy wpływ wywiera adhezja oraz odkształcanie materiału wokół narzędzia. Na podstawie obserwacji makrostruktury złącza można stwierdzić, że zastosowanie prędkości obrotowych 280 obr./min i 355 obr./min pozwala na wytworzenie wystarczającej ilości ciepła do wymieszania materiałów, czyli do utworzenia złącza. Przy prędkościach 450 obr./min i 560 obr./min ilość wytworzonego ciepła maleje, co skutkuje gorszym wymieszaniem materiałów, czego wynikiem jest obecność defektów w złączu. 

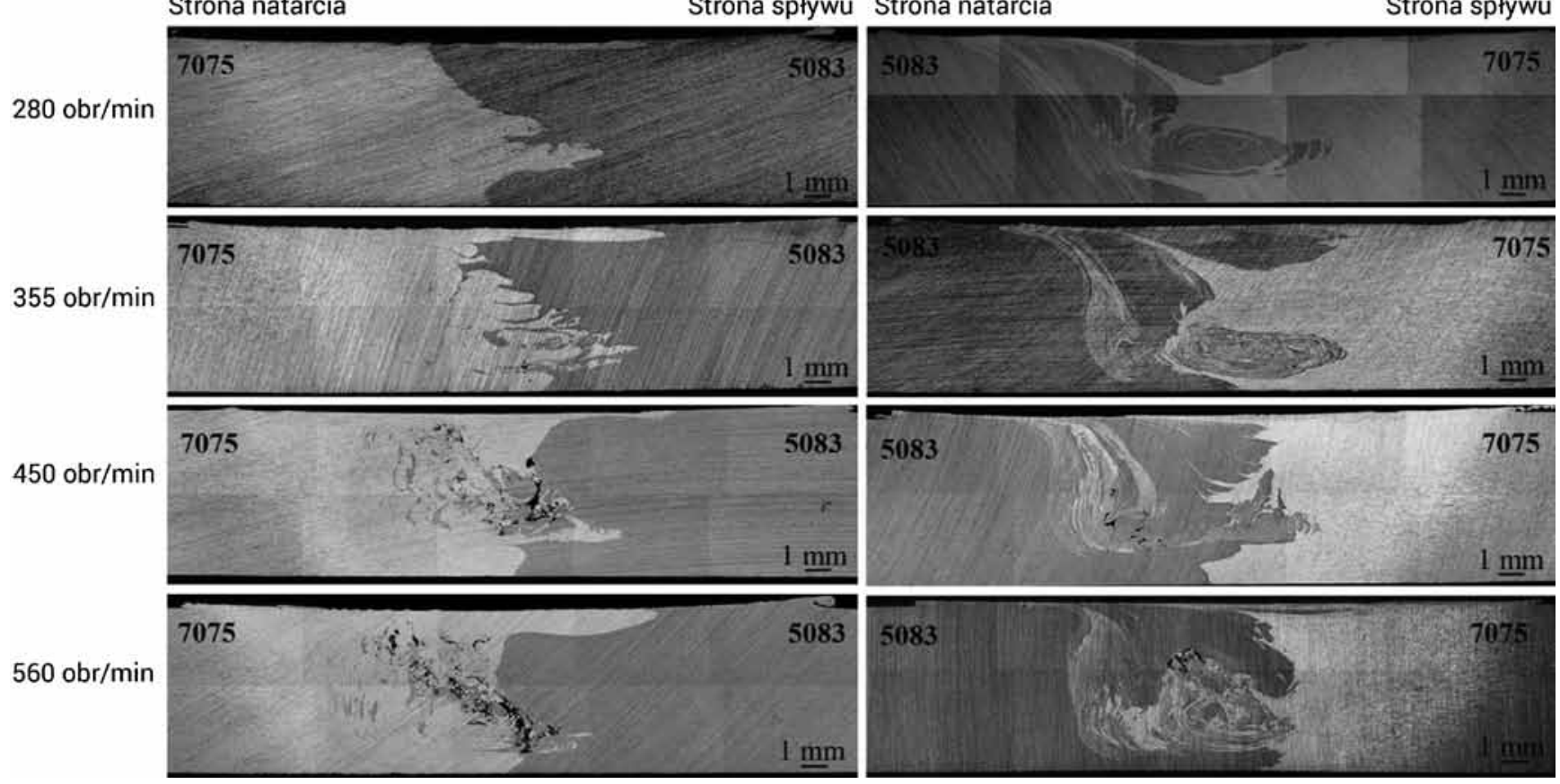

-5083 i 5083-7075

Fig. 3. Macrostructure of welds' cross-section depending on the tool rotation speed observed for $7075-5083$ and $5083-7075$ configurations. Left side of every image refers to advancing side, right side of image - to retreating side.

\section{Mikrostruktura}

Wszystkie otrzymane złącza charakteryzują się asymetrycznością względem środka złącza, ale w każdym z nich można wyróżnić charakterystyczne dla procesu FSW strefy mikrostrukturalne. Na rysunku 4 pokazano mikrostrukturę złącza 5083-7075 z wyróżnionymi strefami: strefą mieszania (SM) znajdującą się w środkowej części złącza, przylegającą do niej po obu stronach złącza strefę cieplno-plastyczną (SCP) oraz strefę wpływu ciepła (SWC). Podobnie jak w przypadku złączy tych samych stopów, poszczególne strefy różnią się wielkością ziaren. W strefie mieszania struktura jest drobnoziarnista, w strefie cieplno-plastycznej ziarna są większe i wydłużone, natomiast strefa wpływu ciepła charakteryzuje się dużym ziarnem. Obszar strefy cieplno-plastycznej jest zdecydowanie szerszy po stronie umiejscowienia stopu 7075 niż stopu 5083, co potwierdza asymetryczność złączy.

Strona natarcia (stop 5083)

Strona spływu (stop 7075)

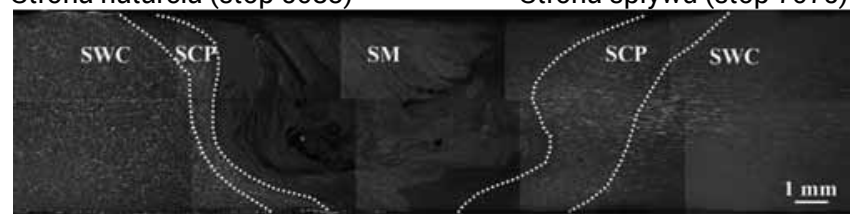

Rys. 4. Mikrostruktura przekroju poprzecznego złącza 5083-7075 (450 obr/min)

Fig. 4. Microstructure of cross-section of 5083-7075 weld (450 rpm)

Mikrostruktura strony natarcia i strony spływu różnią się od siebie (rys. $5 \mathrm{i}$ 6). Bez względu na konfigurację złącza granica pomiędzy strefą mieszania a strefą cieplno-plastyczną po stronie natarcia jest wyraźna (rys. 5a i 6a). Jednoznacznie oddzielony jest obszar o drobnym ziarnie (SM) od obszaru o wydłużonym większym ziarnie (SCP). Natomiast po stronie spływu granicę tę trudno dokładnie wskazać (rys. 5b i 6b). Po stronie spływu obserwowane jest stopniowe przejście od mikrostruktury strefy mieszania (drobne ziarna) do mikrostruktury strefy cieplno-plastycznej (większe odkształcone ziarna).
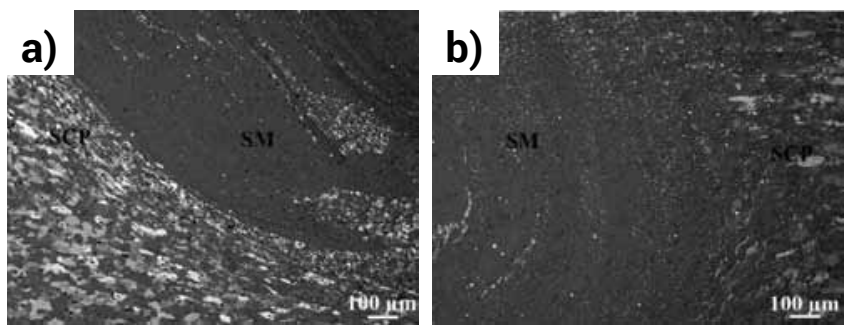

Rys. 5. Mikrostruktura złącza 5083-7075: a) strona natarcia, b) strona spływu; $450 \mathrm{obr} / \mathrm{min}$

Fig. 5. Microstructure of 5083-7075 weld: a) at advancing side, b) at retreating side; $450 \mathrm{rpm}$
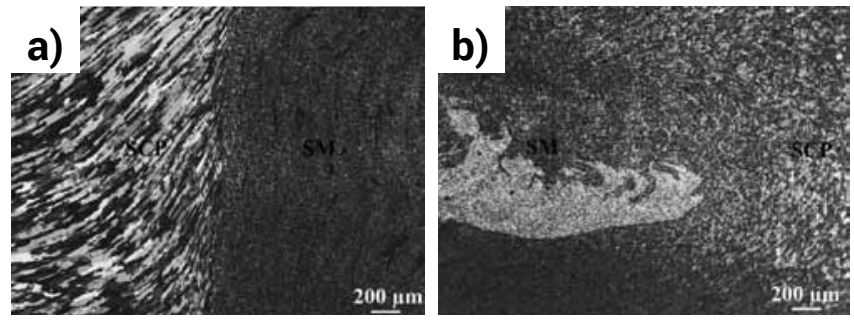

Rys. 6. Mikrostruktura złącza 7075-5083: a) strona natarcia, b) strona spływu; $450 \mathrm{obr} / \mathrm{min}$

Fig. 6. Microstructure of 7075-5083 weld: a) at advancing side, b) at retreating side; $450 \mathrm{rpm}$ 
Centralna część złącza tzw. strefa mieszania w przypadku badanych złączy różnoimiennych ma złożoną mikrostrukturę, charakteryzującą się pasmami pochodzącymi od łączonych stopów (rys. 7). W zależności od prędkości obrotowej w strefie mieszania obserwowane jest mniejsze (rys. 7a i c) lub większe (rys. 7b i d) wymieszanie stopów, o którym świadczy różna ilość pasm pochodzących od danego stopu. Pasma różnią się między sobą także wielkością ziarna.
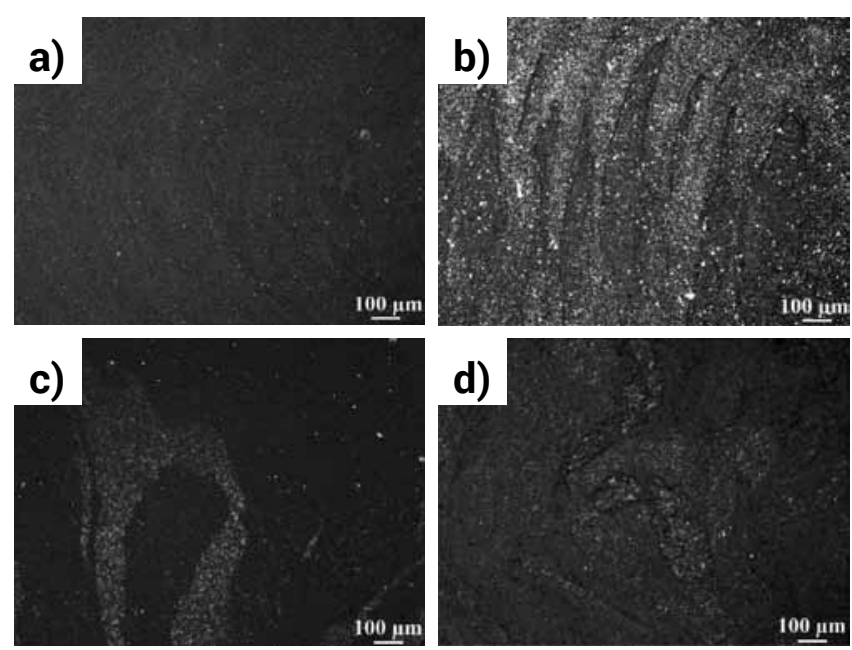

Rys. 7. Mikrostruktura strefy mieszania złączy: a) 7075-5083, 280 obr/min; b) 7075-5083, $450 \mathrm{obr} / \mathrm{min}$; c) 5083-7075, $280 \mathrm{obr} / \mathrm{min}$ d) $5083-7075,450 \mathrm{obr} / \mathrm{min}$

Fig. 7. Microstructure of stirred zone of welds: a) 7075-5083, $280 \mathrm{rpm}$; b) $7075-5083,450 \mathrm{rpm}$; ) $5083-7075,280 \mathrm{rpm}$; d) $5083-7075,450 \mathrm{rpm}$

\section{Twardość}

Na rysunku 8 przedstawiono profile twardości wybranych złączy w dwóch konfiguracjach. Profile twardości ze względu na połączenie dwóch stopów o różnych właściwościach (twardość stopu 5083 wynosi ok. $80 \mathrm{HV}$, a stopu 7075 - ok. 158 HV) wykazują asymetrię względem środka złącza. Zmiany twardości od środka złącza w kierunku stopu 7075 (bez względu na konfigurację złącza) występują na szerszym obszarze niż w stronę stopu 5083. W złączach 7075-5083 obszar złącza sięga do $18 \mathrm{~mm}$ od środka złącza po stronie natarcia i $3 \mathrm{~mm}$ po stronie spływu. Natomiast złącza 5083-7075 obszar złącza od środka złącza po stronie natarcia ma szerokość $8 \mathrm{~mm}$, a po stronie spływu $18 \mathrm{~mm}$. Stąd wynika, że bez względu na umiejscowienie stopu 7075 obszar złącza od jego strony jest stały i wynosi $18 \mathrm{~mm}$. Natomiast umiejscowienie stopu 5083 ma duży wpływ na zakres złącza. Jeśli znajduje się po stronie spływu obszar podlegający działaniu ciepła i odkształcenia podczas procesu zgrzewania jest bardzo wąski. Zmiana umiejscowienia stopu na stronę natarcia powoduje rozszerzenie tego obszaru.

Ze względu na różne zachowanie stopów pod wpływem odkształcenia i temperatury obserwujemy różnice w profilu twardości po stronie natarcia i po stronie spływu. Analizując profil twardości od strony stopu 7075 do środka złącza zachowany jest typowy kształt profilu twardości dla jednoimiennych złączy FSW stopów aluminium serii 7xxx-T6 (rys. 9a), charakteryzujący się minimum twardości na granicy strefy cieplno-plastycznej i strefy wpływu ciepła. W drugiej części profilu twardości badanych złączy brak jest spadku twardości (typowego dla złączy jednoimiennych stopów serii 5xxx-Hxxx (rys.9b). Na granicy SWC i SCP następuje nagły wzrost twardości.

a)

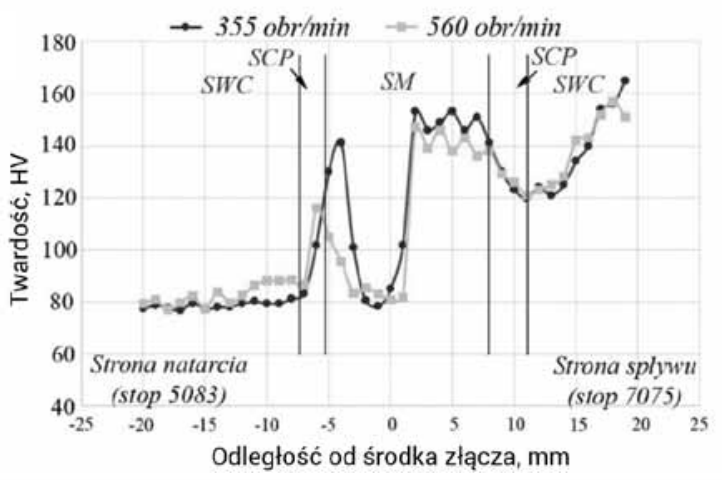

b)

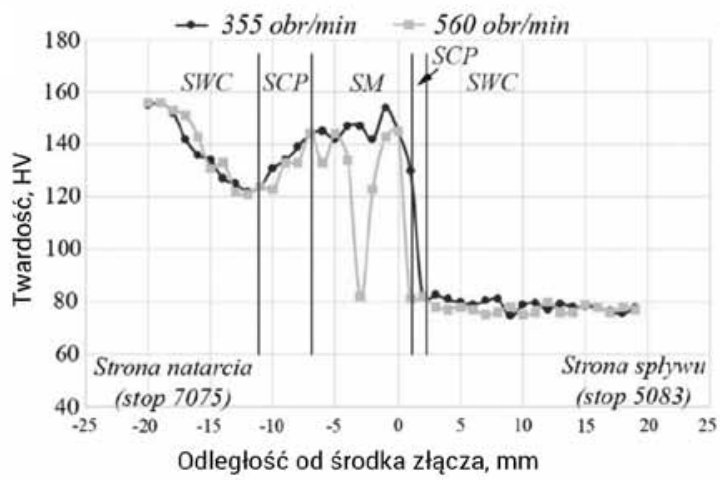

Rys. 8. Profile twardości złączy a) w konfiguracji 7075-5083; b) w konfiguracji 5083-7075 z zaznaczonymi strefami mikrostrukturalnymi Fig. 8. Course of weld hardness profile in the case of a) 7075-5083 configuration; b) 5083-7075 configuration with marked microstructural zones

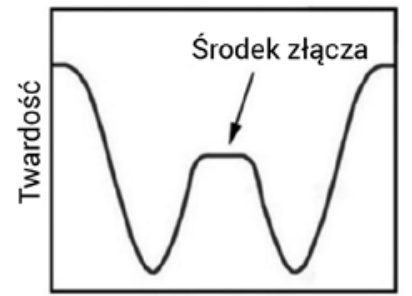

Odległość

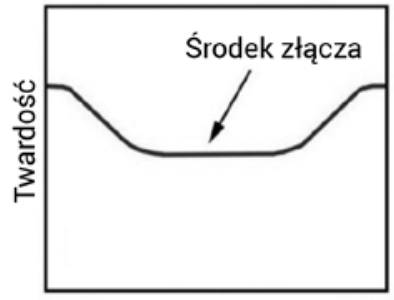

Odległość
Rys. 9. Schemat profilu twardości dla złączy FSW stopów aluminium a) 7xxx po obróbce cieplnej (T6xx, T7xx); b) 5xxx umocnionych przez odkształcenie (Hxxx) [2]

Fig. 9. Hardness profile shape of the FSW aluminium alloys of a) $7 x x x$ series after heat treatment (T6xx, T7xx); b) cold workhardened $5 x x x$ series (Hxxx treatment) [2]

W przypadku obu konfiguracji złączy, centralna część złącza charakteryzuje się dużymi fluktuacjami twardości (od punktów o najniższej twardości $80 \mathrm{HV}$ do punktów o najwyższej twardości ok. $158 \mathrm{HV}$ ). Ta część profilu odzwierciedla obszar strefy mieszania, który ma bardzo złożoną strukturę. W zależności od prędkości obrotowej narzędzia, profil twardości nieco się różni. Dla prędkości 560 obr/min w przypadku obu konfiguracji twardość nieznacznie zmniejsza się. Widocznynagły spadek twardości w odległości ok. $3 \mathrm{~mm}$ od środka złącza w przypadku złącza 7075-5083 dla prędkości 560 obr/min może być spowodowany obecnością porowatości w tym miejscu. 


\section{Właściwości wytrzymałościowe}

Wyniki próby rozciągania zaprezentowano $\mathrm{w}$ formie wykresu obrazującego wytrzymałość na rozciąganie zarówno materiałów wyjściowych, jak i złączy w obu konfiguracjach (rys. 10). Wytrzymałość na rozciąganie stopu 7075 wynosi $604 \mathrm{MPa}$, a stopu 5083-346 MPa. Złącza tych dwóch stopów nieposiadające defektów wykazały wyższą wytrzymałość na rozciąganie niż stop 5083, najwięcej o $25 \mathrm{MPa}$ w przypadku złącza 5083-7075 wykonanego z prędkością obrotową narzędzia $280 \mathrm{obr} / \mathrm{min}$. Dla obu konfiguracji złącza wykonane przy prędkości $560 \mathrm{obr} / \mathrm{min}$ charakteryzowały się najniższą wytrzymałością na rozciąganie, co spowodowane jest obecnością porów. Nie zaobserwowano istotnego wpływu konfiguracji złącza na wytrzymałość na rozciąganie próbek ze złączem. Zerwanie próbek wytrzymałościowych następuje w najsłabszym miejscu, czyli po stronie, gdzie znajdował się stop 5083 lub w przypadku próbek z porowatością $w$ miejscu defektu.

Prędkość obrotowa, a tym samym ilość wytworzonego ciepła ma także wpływ na właściwości wytrzymałościowe powstałych złączy. Zastosowanie prędkości obrotowych $280 \mathrm{obr} / \mathrm{min}$ i $355 \mathrm{obr} / \mathrm{min}$ pozwala na osiągnięcie wysokich wartości wytrzymałości na rozciąganie, odpo-

\section{Wnioski}

Przy odpowiednim doborze parametrów procesu zgrzewania możliwe jest uzyskanie trwałego bezdefektowego złącza pomiędzy stopami 7075-T651 oraz 5083-H111, charakteryzującego się bardzo dobrymi właściwościami wytrzymałościowymi. Wytrzymałość na rozciąganie złączy jest niższa niż stopu 7075 , ale wyższa od wytrzymałości stopu 5083. Im wyższa prędkość obrotowa tym ilość wytworzonego ciepła maleje i w złączu pojawiają się pory dla obu konfiguracji, a co za tym idzie obniża się wytrzymałość na rozciąganie złączy.

Konfiguracja złącza (umiejscowienie danego stopu po stronie natarcia czy spływu) ma istotny

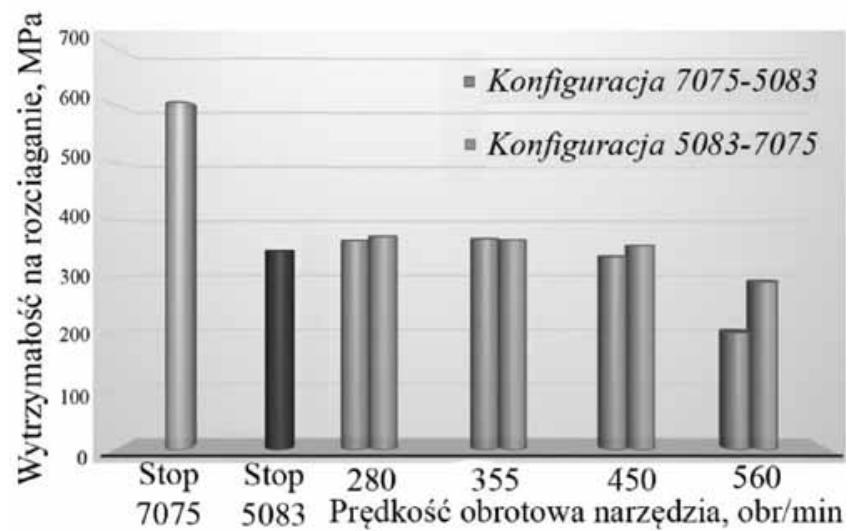

Rys. 10. Wytrzymałość na rozciąganie łączonych stopów oraz złączy w obu konfiguracjach

Fig. 10. Tensile strength of the joined alloys and welds in both configurations

wiednio $364 \mathrm{MPa}$ i $367 \mathrm{MPa}$ dla konfiguracji 7075-5083 oraz $371 \mathrm{MPa}$ i $365 \mathrm{MPa}$ dla konfiguracji 5083-7075. Przy dalszym zwiększaniu prędkości obrotowych do 450 $\mathrm{obr} / \mathrm{min}$ i $560 \mathrm{obr} / \mathrm{min}$ ilość wytworzonego ciepła maleje, co powoduje nieznaczne obniżenie wytrzymałości na rozciąganie złączy. Tendencja taka występuje w obu konfiguracjach ułożenia materiałów do zgrzewania.

wpływ na wymieszanie materiałów w strefie mieszania, ale nie zaobserwowano istotnego wpływu na właściwości wytrzymałościowe złącza. W przypadku konfiguracji 5083-7075 otrzymano lepsze wymieszanie materiałów przy użyciu narzędzia roboczego z trzpieniem typu Triflute.

Złącza wykazują wyraźną asymetrię w położeniu i rozmiarze charakterystycznych stref mikrostrukturalnych względem środka złącza FSW. Mikrostruktura w obszarze strefy mieszania składa się z pasm obu łączonych stopów charakteryzujących się drobnym ziarnem.

Kształt profilu twardości odzwierciedla poszczególne strefy mikrostrukturalne złącza. Fluktuacje twardości w strefie mieszania spowodowane są bardzo złożoną mikrostrukturą w tym obszarze.

„Projekt został sfinansowany ze środków Narodowego Centrum Nauki przyznanych na podstawie decyzji numer DEC-2012/07/D/ST8/02737"

\section{Literatura}

[1] Ambroziak A.: Zgrzewanie tarciowe materiałów o różnych właściwościach, Oficyna Wydawnicza Politechniki Wrocławskiej, Wrocław 2011

[2] Threadgill P.L. i in.: Friction stir welding of aluminium alloys; International Materials Reviews, 54/2009.

[3] Kumar A., Jadoun R.S.: Friction stir welding of dissimilar materials/alloys: A review; International Journal of Mech. Eng. \& Rob. Res. Special Issue, 1/2014, s.106-112.

[4] Pietras A., Adamiec J.: Zgrzewanie aluminium z miedzią metodą FSW; Biuletyn Instytutu Spawalnictwa, 49 (5)/2005, s. 133-137.
[5] L.E. Murr, A review of FSW research on dissimilar metal and alloy systems, Journal of Materials Engineering and Performance, 19/2010, s. 1071.

[6] Shojaeefard M.H. i in.: Modelling and Pareto optimization of mechanical properties of friction stir welded AA7075/ AA5083 butt joints using neural network and particle swarm algorithm, Materials and Design, 44/2013 s.190.

[7] Chao Y. Tang W.: Heat Transfer in Friction Stir Welding - Experimental and numerical studies, Transactions of the ASME, 2003, s. 125. 